\title{
BUILDING A CITY BRAND ON THE BASIS OF ACTIVITY OF CITY THEATRES
}

\author{
Wawrzyniec Rudolf* https://orcid.org/0000-0003-0729-7823 \\ Ewa Glińska** https://orcid.org/0000-0002-2121-0125
}

\begin{abstract}
Background. The challenge of building a strong territorial brand is an area of growing interest among practitioners and academics alike. Culture, which is an important element of local identity, is increasingly used as a basis for building a territorial brand. Its important creators are local cultural institutions, such as theatres, museums, or galleries. In Poland, public cultural institutions have a high degree of autonomy towards local authorities / local administration and their effective inclusion in the processes of building a territorial brand requires adopting an adequate approach.
\end{abstract}

Research aims. The aim of the paper is the identification of ways in which cultural institutions can cooperate with local administration to build a brand of a city. On account of the varying roles of individual types of cultural institutions in the process of communicating the city brand, our deliberations have been limited to theatres.

Methodology. To implement this goal the authors used the case study method. The analysis considered two cities: Bialystok and Lodz. The selection of these cities was connected with the clearly accented role of culture in the development strategies of these two urban centres. The case study made use of individual in-depth interviews with theatre managers as well as with heads of municipal office departments responsible for promotion within the two cities covered by the analysis.

Key findings. In the paper, the authors: determine the types of shared projects implemented by theatres and local administration contributing to the development of a city brand, diagnose the benefits resulting from this type of cooperation for both parties, as well as formulate conditions for the success of this type of cooperation.

Keywords: city brand, cultural institutions, theatres, interorganisational cooperation JEL Codes: R58, H83, M3

* University of Lodz, Faculty of Management, 22/26 Matejki Street, 90-237 Lodz, Poland. E-mail: wawrzyniec.rudolf@uni.lodz.pl.

${ }^{* *}$ Bialystok University of Technology, Faculty of Engineering Management, 45 A Wiejska Street, 15-351 Bialystok, Poland. E-mail: e.glinska@pb.edu.pl. 


\section{INTRODUCTION}

The adaptation of the concept of the brand into city management practice is an area which is gaining more and more interest, both from the scientific community as well as from practitioners. Brands are becoming a part of the public sphere and local authorities are starting to appreciate their value. Culture, understood as the local activity of cultural institutions which often transcends the territorial boundaries of a given city, is especially significant among the numerous sources of city brand identity.

The aim of the paper is the identification of ways in which cultural institutions, mainly city theatres, cooperate with local administration to develop a city brand. Primarily, the authors focus on:

- determining the actual and potential categories of projects implemented together by city theatres and local authorities meant to develop a city brand,

- diagnosis of benefits for both parties from this type of cooperation,

- formulation of conditions necessary to make this cooperation effective.

To implement this goal the authors used the research method of the case study. The analysis considered two cities: Bialystok and Lodz. The selection of these cities was connected with the clearly accented role of culture in the development strategies of these two urban centres. As part of the case study analysis a total of 10 individual in-depth interviews were carried out with managers of theatres operating in Lodz and Bialystok as well as with heads of municipal office departments responsible for city promotion and cultural policies of these two cities.

Research performed within the scope of the paper is explorative in its nature because, according to the knowledge possessed by its authors, a research problem thus defined has not been addressed within the subject-related literature. The authors decided to get in touch with both sides of this relationship, to the institutional stakeholders - municipal offices and cultural institutions, represented by theatres, to discover the assessment of their cooperation in relation to building a city brand as well as identify possible opportunities for its intensification. 


\section{THE ROLE OF CULTURE IN THE PROCESS OF BUILDING A CITY BRAND - LITERATURE REVIEW}

Within the last two decades the concept of territorial marketing has become a subject of growing interest, both among representatives of the academic community as well as local government practitioners. This situation, to a great degree, is the result of the undoubted impact of a recognisable city brand on decisions connected with the selection of a given urban centre by tourists as well as its current and future inhabitants.

Territorial marketing has evolved along with the passage of time as well as the appearance of new, interesting issues within this area of knowledge. According to the opinion of Kavaratzis (2008), the current stadium of its development is place branding. This means that marketing efforts of territorial entities, including cities, are more and more often focused on producing associations with a given place that are emotional rather than functional in character (this, however, does not mean that those associations are wholly ignored within the process of brand building) (Florek, 2014, p. 28).

A comprehensive definition of a place brand is provided by Zenker and Braun (2010) who define it as "a network of associations within the minds of customers which is based on visual, verbal and behavioural expression of a place embodied through goals, communication, values and general culture of the place's stakeholders and its overall design". A city brand, therefore, is the general image as well as a set of associations connected to a city, which exist within the perceptions of particular target groups of marketing operations initiated by urban self-governments (Zenker, 2011). The notion of the brand is connected with the concept of branding which covers intentional activities oriented on changing or improving that image (Baker, 2012, p. 18). These activities include designing, planning, and communicating the city brand identity in order to create its desired image as well as its management (Anholt, 2007, p. 11). According to Klijn, Eshuis and Braun (2012) brands are supposed to communicate selected characteristics of a given city imbuing them with specific meaning. In making a decision to pursue the strategic approach to shaping the desired image of a city, local self-governments search for elements of identity which will allow them to build an attractive 
image both externally as well as internally (understood as the way in which it is perceived by its inhabitants) (Glińska \& Florek, 2013). Characteristics which make the city stand out may, among others, include: its architecture, history, demography, natural assets as well as the local cultural offer. The role of cultural attractions in defining a city's identity is underlined, for example, by Zenker (2009), Merrilees et al. (2012), Gilboa et al. (2015), and Glińska (2014 and 2016). Through their research they point to the significant role of the city's cultural offer in the process of building a city brand identifying such elements as: the presence of flourishing cultural institutions, organisation of events and festivals, live entertainment as well as a wide spectrum of opportunities for enjoying culture during free time.

The inclusion of cultural institutions in the process of city branding is also connected with the participational character of this process. Kavaratzis and Hatch (2013) write that place branding should be understood as a dialogue or a debate between stakeholders since brands are built from the "raw material" of identity while identity emerges as the result of the exchange between the interested parties and all things which they share. This, therefore, means that the role of local self-governments consists of initiating, facilitating, and stimulating the dialogue essential for building a place brand.

While planning the process of city brand management consideration for the group of stakeholders represented by cultural institutions and referring to activities initiated by them is becoming more and more important. Subject related literature confirms that, to a large degree, cultural institutions impact the socio-economic development of a territorial unit including also the shaping of a place brand. After all, these institutions have a significant share in the creation of the unique atmosphere and character of the place, influencing its "creative atmosphere" (Działek \& Murzyn-Kupisz, 2014).

It is also worth mentioning that cultural institutions such as museums, art galleries, and theatres provide citizens with a lot of value and are a potential magnet for attracting visitors. Unfortunately, according to the opinion of Stubbs and Warnaby (2015), many cities do not know how to take advantage of the full potential of these resources. This is also true of cultural events. Numerous happenings are organised within particular cities but these often occur in isolation. Combining them into a single whole may determine the cultural offer of a place and have a strong impact on its brand. 
Within the practice of Polish local governments it is possible to see differences in the degree to which the needs for the development of the cultural sphere are addressed through the decisions made by local authorities. The local territorial units' approach to culture is influenced not only by the budget of a given entity but also the qualifications and engagement of people managing its cultural institutions who, thanks to their competencies and creativity, can surmount many barriers (Mazurek-Łopacińska \& Sobocińska, 2012). A condition for the utilisation of the cultural sphere in the creation of a city brand is the presence of an appropriate cultural infrastructure as well as a unique cultural offer created by cultural institutions (Sobocińska, 2009). The broadly understood cooperation between local administration with institutional stakeholders from the local and regional culture market is an important element of this process.

Cooperation between organisations has been described in numerous economic theories, of which the resource dependency theory, social exchange theory as well as transaction cost theory are worth mentioning (Rudolf, 2016, pp. 92-97). However, descriptions of interorganisational relations in the context of governance processes most often use the resource dependency theory (Klijn \& Koppenjan, 2016). This theory is founded on the conviction that there are interrelations between organisations which are the consequence of having or not having various resources (financial, material, relational, or symbolic) needed for the realisation of the organisation's goals. A deficit of particular resources in one organisation leads to attempts to influence others who have such resources at their disposal (Pfeffer \& Salancik, 1978). Within this context, the aim of the organisation is to gain control over resources on which the implementation of their strategic goals is dependent. In situations where these resources are scarce, a possible strategy for the implementation of the goals is their acquisition from other entities with cooperation becoming one of the main tools in the process of acquiring them (Donaldson \& O'Toole, 2002).

The use of the dependency theory as a theoretical reference in the description of the relationship existing between the city's administration and cultural institutions is supported by the fact that it is formulated on the level of analysis typical to the organisation (in this case the municipal office). It assumes the perspective of the organisation's management which looks out into its surroundings (Hatch, 2002). Cultural institutions, characterised by a relatively large measure of 
autonomy in relation to their facilitator, the local self-government, while at the same time having no clearly defined tasks concerning the promotion of the city, can be treated as the municipal office's stakeholders. They administer resources in the area of culture which can be used as part of the policy for the building of a city brand's image. Local administration (including departments for promotion and departments for culture) can attempt to influence theatres, both through formal activity based on their administrative relationship, as well as informal activity based on trust or the bonds established by the participants of these processes.

\section{METHOD}

An important trend currently observed within the area of management science is the utilisation of qualitative methods allowing a more precise grasp of the specific character of the phenomena accounting for the impact of non-measurable or difficult to measure variables on the processes of managing contemporary organisations. One of such qualitative methods is the case study (Matejun, 2011, p. 203). This method allows the interpretative understanding of reality. As an idiographic study it allows for presenting the differences and similarities between individual cases to identify tendencies (Creswell, 2013). The present study made use of the case study embedded in the organisational, demographic, political, and geographic contexts (Yin, 2009). A decision to select two, characteristics, varying in size and other contexts, potentially significant to the object of research, of the 16 Polish provincial capitals, was made.

Activities within the field of cultural development, in Poland entrusted to local governments, can be implemented in two ways - through facilitation (establishment and oversight of cultural institutions) and through support for cultural activity (especially that of NGOs operating within this sphere). Local governments usually fulfil their assigned tasks primarily through the use of institutions which they have established for this purpose while all other instruments (financing of NGOs, awards, grants, etc.), considering the amount of resources spent on them, are treated optionally.

In the process of final selection, the authors decided on the post-industrial city of Lodz, a centrally located and third largest city in Poland, 
and Bialystok, a significantly smaller urban centre, the capital of the Podlasie Province, located in the outlying area of Poland. However, the criterion which connects both places is the fact that within the last decade they have heavily invested in activities meant to build their city brands on the basis of culture. It must be stressed that both cities function under the same administrational and political conditions (they are both capitals of their respective provinces, formally independent from other levels of national and local administration, are obligated to carry out promotional activities and have a culture development policy founded on cultural institutions) as other Polish cities which have accepted the challenge to build their city brand image on the basis of local cultural resources. These and other characteristics differentiating the two cities have been presented in Table 1.

These two cities clearly differ, however, when it comes to the organisational network of cultural institutions, also within the context of numbers and specific character of local theatres (Table 1). There are also significant differences in the organisational structures of municipal offices as regards the implementation of tasks concerning promotion and culture.

Table 1. Characteristics differentiating the considered urban centre in the context of the research problem being addressed

\begin{tabular}{|l|c|c|}
\hline & $\begin{array}{c}\text { Lodz (Lodz } \\
\text { Province) }\end{array}$ & $\begin{array}{c}\text { Bialystok (Podlasie } \\
\text { Province) }\end{array}$ \\
\hline $\begin{array}{l}\text { Number of cultural institutions facili- } \\
\text { tated by city government }\end{array}$ & 21 & 7 \\
\hline Number of public city theatres & 5 & 297.3 \\
\hline Number of inhabitants (in thousands) & 690.4 & $1,184.5$ \\
\hline $\begin{array}{l}\text { Number of the Province's inhabitants } \\
\text { (in thousands) }\end{array}$ & $2,476.3$ & 194.5 \\
\hline $\begin{array}{l}\text { Level of expenditure for culture and } \\
\text { the protection of national heritage by } \\
\text { local governments within the Province } \\
\text { (M of PLN) }\end{array}$ & 405.3 & \\
\hline
\end{tabular}

Source: Bulletin of Public Information 2018 (access: 12.08.2018); Statistics Poland, Local Data Bank 2018.

Within their strategies for regional development both cities placed a lot of emphasis on the area of culture. In the Strategy for the Development of the City of Lodz 2020 Plus culture makes up one of the 
strategy's three pillars ("Society and culture") preceded by "Economy and infrastructure" and followed by "Space and the Environment". On the other hand, in a document concerning the city of Bialystok, culture was mentioned as one of its five strategic goals, listed in the fourth spot under: "Attractiveness and accessibility of the cultural, sport and recreational offer". It must also be said that the Strategy for the Development of the City of Bialystok for 2011-2020, as early as its diagnostic portion (SWOT analysis), mentions the Bialystok Puppet Theatre by name as a source of the city's prestige and as the "the city's most frequently awarded cultural institution both nationally as well as internationally". At the sector level, however, it is the city of Lodz which can boast having separate planning documentation for the area of city promotion/brand or for the cultural sphere. References to the cultural identity of the city as well as its promotion are clearly placed within the Policy for Cultural Development of Lodz 2020+. Its first strategic goal is defined as: "Identity: development of strategic areas of culture". The subject matter of promotion can, on the other hand, be found in one of the tasks which operationalise this aim: "Accounting for city cultural institutions in the city's promotional campaigns". Furthermore, in the Strategy for the Brand and Promotion of the City of Lodz for the Years 2010-2016 passed in 2017, culture, next to economy, education and sport, was a key component of the city's message. When it comes to Bialystok, until recently, urban sector level strategies have not existed in such concise form and the formulated in 2018 "Programme for the cultural policy of the city of Bialystok 2018-2020 plus" is relatively synthetic and does not address subject matter connected to city promotion, image or brand. This means that in respect to Lodz, subjects being considered within this study have been more broadly described in formal documentation, which should be seen as a sign of consideration for formal issues typical to the administrative approach.

As part of the more thorough case study analysis the authors carried out individual in-depth interviews (IDI) with people representing the management of theatres operating in Lodz and Bialystok as well as with supervisors of organisational units of the municipal offices of these two urban centres responsible for culture. In total, for the needs of the paper, 10 interviews were conducted with people holding management positions within the considered institutions. Interviews in Lodz were carried out with respondents in the following institutions: 
the Henryk Ryl "Arlekin" Puppet Theatre, "Pinokio" Music Theatre of Lodz, Kazimierz Dejmek New Theatre, Powszechny Theatre; municipal office institutions: Promotional Office of the Lodz Municipal Office (2 interviews), Department of Culture. Interviews in Bialystok were carried out with respondents from the following institutions: the Bialystok Puppet Theatre and the Department for Promotion, Culture and Sport of the Bialystok Municipal Office.

Two versions of a script for the interview - the chosen research instrument, were developed. One of these was adapted to be used with people managing theatres while the other was intended for supervisors of particular organisational units operating within the municipal offices. The questions contained in both scripts were open ended in character and dealt with detailed research aims described at the onset of this work.

Since all theatres located in Lodz were established between 1945 and 1949 they are considered to be relatively new. Although contemporary theatres try to present themselves as organisations which offer a broad range of cultural services the New Theatre, under the patronage of Kazimierz Dejmek, can be considered to be a dramatic theatre, the Powszechny Theatre - a comedic one while the Music Theatre can be dubbed an operetta theatre. The other two theatres in Lodz - the "Pinokio" Puppet and Actor Theatre as well as the "Arlekin" Puppet Theatre address their offer mainly to the youngest audiences. Their repertoire is broadly constructed - somewhere between the classic fairy-tale, contemporary children's literature, and original stage exploration. The Bialystok Puppet Theatre was established in 1953. Currently it is the only theatre financed by the local government. It carries out activities which focus on three subject matters: plays for children, plays for adults as well as exploratory and experimental performances.

\section{RESULTS AND DISCUSSION}

In the course of the interviews carried out with respondents representing both theatres and local authorities, the interviewers asked about cooperative initiatives being implemented with the aim of building city brands. The analysis of the results allowed the authors to ascertain that the theatres from Lodz have been involved in building the city's brand 
through activities in the area of marketing communication. Initially, this was accomplished through a decree issued by the city's Mayor obligating local institutions to utilise the city logo, in accordance with the established system of visual identification, in media-related activities which they conducted. The rule that important cultural events would be announced with the involvement of the Mayor, through her press office, was also introduced. The aim was to create a stronger association of these events and cultural institutions with the city. Additionally, in previous years, the Promotional Office of the Lodz Municipal Office, invited the theatres to participate in the city's festival by running promotional stands. Sporadically, the theatres also took part in the artistic portion of the annual Lodz Days, performing their plays on its outdoor stage. Participation of the city's theatres in international exchange programs being part of the network of city partnerships were also considered by respondents as part of this type of activity.

From the opinions of the respondents it can be seen that, sporadically, there are initiatives taking place in Lodz introduced by the city's cultural institutions which could positively impact the city brand meant to be seen by the outside world. The cooperation of the New Theatre from Lodz with the Imka Theatre from Warsaw, involving the exchange of plays and shared productions, can be considered a part of this trend. Initiatives connected with the promotion of theatres carried out up to now also include the "Touch Theatre" project which had its start in Lodz and later "flooded" the entire nation.

More examples of cooperation between the local administration and the theatre can be shown in respect to Bialystok. As one such instance the respondents mentioned a joint event focusing on the promotion of theatres among the inhabitants of the city and the region the International Festival of Puppetry Schools which is included in the agenda of Bialystok Days. This festival, according to the opinion of the interviewee (the manager of the theater) "enriches the local cultural offer providing the inhabitants of Bialystok and the Podlasie Province with the opportunity to see plays, small theatrical forms, and exhibitions". One special characteristic of the Festival is the promotion of the puppet theatre directed at adult viewers. Good practices in the cooperation of the local administration and the Bialystok Puppet Theatre also include the participatory preparation of the document: the Cultural policy of the city of Bialystok, which occurred in 2018 and consisted of a number of working meetings between people representing 
local cultural institutions and members of the local administration. Another example of joint initiatives aimed at building the city brand is the membership of the local government in an association promoting particular theatrical forms. The city of Bialystok joined the International Association of Puppet Friendly Cities, an international organisation which affiliates city representatives and cooperates with people of culture as well. Thanks to this initiative, the manager of the Theatre represents the city in the association's conferences held abroad which occur several times a year.

Yet another issue that was addressed during the interviews was the benefits which the two sides involved in such cooperation can gain thanks to joint initiatives meant to build the city's brand. These benefits were considered through the prism of both perspectives, that of the theatres as well as the municipal offices.

Some respondents representing the theatres from Lodz see such benefits in the expanded opportunity to reach out with their offer to a broader group of viewers. One of the managers taking part in the study confirms these expectations by saying: "we would like to stage plays within the entire Province (not only in Lodz)". The participants also saw chances for theatres from the city to present their offers on international markets (in the form of international tours). There was also mention of the need to "get through" to the national or international media but that requires financial support. This is exemplified in the following statement: "we are doing ok on the local market - our audiences are full - but in those large projects which we are realising, that involve big money, additional funding, sponsors, etc, [we need] promotional support, and probably financial as well".

Similar benefits were also pointed out in Bialystok. Cooperation with the city brings the theatre promotional benefits also connected with the building of the brand of the cultural institution itself as well as with being able to utilise a broader spectrum of communication channels (e.g. city initiatives in which the Theatre is involved are written about and presented in, among others, the city's official and unofficial web pages and in other media).

In turn, benefits gained through cooperation with cultural institutions named by representatives of the municipal offices include an increase in city recognition and its identification with a popular subject matter - culture. Within the last five years the Bialystok Puppet Theatre has earned over 50 awards. It was even stressed by the 
theatre's manager during his interview: "well, we don't only promote our art but the name of the theatre does include Bialystok since our name is the Bialystok Puppet Theatre".

Conversations with theatre managers also touched upon motivational elements which could be an incentive for greater engagement in the activities of the local administration connected to the development of a city brand. The spirit of the responses provided by city theatres from Lodz is contained within the following statement: "What would be the best incentive? The only thing that matters is money. If I have more money then, I think, there won't be any problem in promoting the theatre and through that promoting Lodz because always through promoting the theatre we make sure to make it clear that we are an institution from Lodz. The ideas are there, the energy is there, all we need is the means". In turn, the manager of the Bialystok Puppet Theatre emphasised that additional motivation is not necessary because: "we are always promoting the city. It always happens in cooperation with the city since even when we plan financial matters we account for spending for tours to festivals in cooperation with the city. Hence, that kind of cooperation is a normal field of the theatre's activity".

Participants also described conditions for effective cooperation on the theatre - local administration line. The responses of the respondents representing the theatres from Lodz included the following suggestions:

- The need to create a good atmosphere which is conditioned on trust. As stated by one of the theatre managers: "trust, I think that trust is here the foundation of this type of relationship and this also concerns finances because we always have to apply... We are fighting for some grants, battling for some additional funding from large initiatives and if there is no trust then, for sure, it is more difficult to get some financial resources and, without them, it is more difficult to build something".

- Human touch and kindness - the municipal office should support theatres not only financially but also provide personal and substantive support.

The following issues were mentioned among the conditions of effective cooperation between theatres and local administration in the city of Bialystok: exchange of information, better communication including direct meetings between local administration and representatives of cultural institutions and non-governmental organisations (for example, meetings between representatives of cultural institutions and local 
administration organised as part of work on developing the city's cultural policy were considered a perfect opportunity for the exchange of such information).

From the perspective of representatives of Bialystok Municipal Office, the conditions for the effective cooperation between the city's theatres and local administration included: mutual openness, willingness to cooperate through the engagement of possessed resources and skills, dialogue and not only demands or the one-sided transfer of information, and seeking solutions rather than problems. The respondents representing the local administration of Lodz, on the other hand, mainly listed two factors: access to funds for promotion and the clear strategic guidelines, meaning the specification of priorities for cooperation in agreed upon strategic and operational documents. The key role of the local leader - the city Mayor, whose job is to integrate the local administration and all departments of the municipal office around strategic aims of development, was also mentioned.

The next issue which was addressed during the interviews was the identification of ideas for future cooperation of theatres with the city in relation to building a city brand. Among those types of ideas presented by the theatres from Lodz were:

- inclusion of offers of all institutional stakeholders of that market (not only those supported by the city) within the cultural portal administered by the city;

- development of a strategy for the promotion of culture within the city/region which would permanently involve the city's promotional department in its relationship with theatres or, more broadly, with cultural institutions operating within the city;

- improvement of the system for the transfer of promotional materials to theatres from Lodz departing for international tours as well as to foreign guests attending local cultural festivals (coming to shows).

Theatre managers from both cities also suggested that the potential of international partner cities in the future cooperation with local administration meant to promote the brands of Lodz and Bialystok should be better utilised. 


\section{CONCLUSIONS}

The conducted research allows the formulation of general conclusions which can become the object of further scientific study as well as conclusions which relate directly to the cases described. General conclusions, which can also be treated as hypotheses relating to the problem of interorganisational relations from the perspective of the resource dependency theory, have been presented first.

Cultural institutions such as theatres can become an element differentiating a city's offer and become a part of a Unique Selling Proposition (USP). It seems, however, that the success of such a solution depends on the theatre's reputation and its international recognition. Cultural institutions can and should be utilised in the process of building a city brand, however, the effectiveness of such activity depends on the cultural identity of the city. The role of cultural institutions within the social life of a given territory, social engagement and support for cultural institutions are factors which directly impact the success of such activities.

The gathered qualitative research material provides foundations for the suggestion of the two hypotheses which should be tested on a statistically significant sample of theatres or, more broadly, institutions dealing with culture in Poland.

The first one would be: The more significant the resources of a cultural institution (institutional stakeholder) the higher level of collaboration between the local administration and the stakeholder in the domain of city brand policy implementation.

The above hypothesis refers to the dependency theory present in management sciences, dedicated to the business sector since the late 1970s (Pfeffer \& Salancik, 1978). Recently it has also become used to describe governance networks (Klijn \& Koppenjan, 2016), or interorganisational relations in the context of providing public services (Ghobadian, Viney \& Redwood, 2009). The assumption of this hypothesis is justified through the fact that among the studied theatres relations with local administration were assessed the highest by the Bialystok Puppet Theatre and the New Theatre from Lodz which among the participating cultural institutions stand out through their widely recognised brands and high level of infrastructure. 
In our case the proposed hypothesis may refer both to the intangible assets of cultural institutions, such as: recognisable brand of a theatre or another service provider, high artistic level of presented matters within the country or the international environment, or tangible assets. In respect to that last category it is possible to list its exemplary elements: an impressive building, modern auditorium, or prestigious location. This hypothesis may be tested in relation to urban cultural institutions or city theatres but only after the completion of an appropriate identification process of various types of public service providers and may also concern wider groups of institutional local government stakeholders.

The policy of city branding is horizontal in nature and requires, among others, the involvement of entities providing public services whose main function is the implementation of a specified range of functional public policies (e.g. cultural, education, or sport policies). Therefore, for example, public cultural institutions are providers of services whose scope and scale are determined by the local cultural policy. Their potential role in the process of building the city's brand, however, will require different relations with local administration, conditioned to a lesser degree through formal dependence and more through a non-formal dependence, accounting for people managing and working toward the betterment of these organisations.

Therefore, the second of the proposed hypotheses refers to the method of building relationships between the parties in the context of building a city brand: The mutually beneficial relationship: local administration - cultural institutions, requires the simultaneous initiation of formal as well as informal activities.

This hypothesis comes from the statements of the respondents who referred to the desired positive atmosphere in relations with the local administration. While the case analysis of the city of Lodz leads to the conclusion that in the relationship between the local administration and the city's theatres there was a lack of such informal activities which, potentially, could have improved it. Respondents listed numerous suggestions whose implementation could have beneficially influenced the relationship: presence of people representing local authorities and the city's department for promotion at the theatre shows and premieres, working meetings dealing with the building of the city's brand with the participation of cultural institutions and the inclusion of the offers of the Province's cultural institutions as well as community 
and private institutions in the cultural offer presented by the city. The lack of integrated local initiatives oriented on the promotion of culture, despite the presence of such responsibilities in the standing strategy for the development of culture, was also stressed.

In respect to Bialystok, the city's smaller scale of local administration development as well as the small number of existing cultural institutions significantly simplifies the management process of building a city brand involving cultural institutions. Thanks to that, Bialystok is much better at utilising the local potential of the theatre and taking advantage of it for the development of the city's brand. Additionally, the international renown of the Bialystok Puppet Theatre fosters the use of that institution to advance the interests of the city.

\section{REFERENCES}

Anholt, S. (2007). Tożsamość konkurencyjna. Nowe spojrzenie na markę. Warszawa: Instytut Marki Polskiej.

Baker, B. (2012). Destination Branding for Small Cities. Portland, Oregon: Creative Leap Books.

Creswell, J. W. (2013). Projektowanie badań naukowych. Metody jakościowe, ilościowe i mieszane. Kraków: Wydawnictwo Uniwersytetu Jagiellońskiego.

Donaldson, B. \& O’Toole, T. (2002). Strategic Market Relationships: From Strategy to Implementation. Chichester: John Wiley.

Działek, J. \& Murzyn-Kupisz, M. (2014). Rola instytucji kultury w budowaniu i wzmacnianiu kapitału społecznego jako czynnika rozwoju społeczno-gospodarczego. In: A. Klasik (ed.). Sektor kreatywny jako katalizator przemian strukturalnych w regionie. Katowice: Wydawnictwo Uniwersytetu Ekonomicznego w Katowicach.

Florek, M. (2014). Kapitał marki miasta zorientowany na konsumenta - źródta i pomiar. Poznań: Wydawnictwo Uniwersytetu Ekonomicznego w Poznaniu.

Ghobadian, A., Viney, H. \& Redwood, J. (2009). Explaining the unintended consequences of public sector reform. Management Decision, 47(10), 1514-1535.

Gilboa, S., Jaffe, E. D., Vianelli, D., Pastore, A. \& Herstein, R. (2015). A summated rating scale for measuring city image. Cities, 44, 50-59.

Glińska, E. (2014). Próba wskazania uniwersalnych zasad dotyczących wyboru atrakcyjnych marketingowo atrybutów małych i średnich miast. In: E. Glińska \& U. Kobylińska (eds.). Identyfikacja cech wyróżniajacych tożsamość 
miasta $w$ procesie zarzadzania jego marka. Białystok: Oficyna Wydawnicza Politechniki Białostockiej.

Glińska, E. (2016). Budowanie marki miasta. Koncepcje, warunki, modele. Warszawa: Wolters Kluwer.

Glińska, E. \& Florek, M. (2013). In searching for town brand distinguishing features - local leaders' inner perspective. International Journal of Academic Research. Part B, 5(4), 200-205.

Hatch, M. J. (2002). Teoria organizacji. Warszawa: Wydawnictwo Naukowe PWN.

Kavaratzis, M. (2008). From city marketing to city branding: An interdisciplinary analysis with reference to Amsterdam, Budapest and Athens, http://dissertations.ub.rug.nl/faculties/rw/2008/m.kavaratzis (access: $22^{\text {nd }}$ June 2017).

Kavaratzis, M. \& Hatch, M. J. (2013). The dynamics of place brands: An identity-based approach to place branding theory. Marketing Theory, 13(1), 69-86.

Klijn, E. H. \& Koppenjan, J. F. M. (2016). Governance Networks in the Public Sector. Oxon: Routledge.

Klijn, E., Eshuis, J. \& Braun, E. (2012). Stakeholder involvement on the effectiveness of place branding. Public Management Review, 14(4), 499-519.

Matejun, M. (2011). Metoda studium przypadku w pracach badawczych młodych naukowców z zakresu nauk o zarządzaniu. Zeszyty Naukowe Uniwersytetu Szczecińskiego, 666, Problemy Zarzadzania, Finansów i Marketingu, 19, 203-213.

Mazurek-Łopacińska, K. \& Sobocińska, M. (2012). Współpraca jednostek samorządu terytorialnego z instytucjami kultury na Dolnym Śląsku. Handel Wewnętrzny, lipiec-sierpień.

Merrilees, B., Miller, D. \& Herington, C. (2012). Multiple stakeholders and multiple city brand meanings. European Journal of Marketing, 46(7/8), 1032-1047.

Pfeffer, J. \& Salancik, G. R. (1978). The External Control of Organizations. New York: Harper and Row.

Policy for Cultural Development of Łódź 2020+ (2012). http://archiwum.bip.uml.lodz. pl/_plik.php?id=31522\&PHPSESSID=6a9dd6fe6a899f5f48d597b51992ec80 (access: $22^{\text {nd }}$ June 2017).

Program for the Cultural Policy of the City of Biatystok 2018-2020 Plus (2018). https://www.bialystok.pl/pl/dla_mieszkancow/kultura/programpolitykikulturalnejmiastabialegostoku (access: $22^{\text {nd }}$ June 2017).

Rudolf, W. (2016). Marketing terytorialny w ujęciu relacyjnym. Łódź: Wydawnictwo Uniwersytetu Łódzkiego.

Sobocińska, M. (2009). Rola instytucji kultury w kreowaniu marki miasta. Marketing i Rynek, 1, 22-30. 
Strategy for the Development of the City of Łódź 2020 Plus (2012). https://uml.lodz. pl/dla-mieszkancow/o-miescie/strategia-lodzi-i-planowanie/strategia-zintegrowanego-rozwoju-lodzi-2020 (access: $22^{\text {nd }}$ June 2017).

Strategy for the Development of the City of Biatystok for 2011-2020 (2010). Retrieved from: https://www.bialystok.pl/pl/dla_biznesu/rozwoj_miasta (access: $22^{\text {nd }}$ June 2017).

Strategy for the Brand and Promotion of the City of Eódz for the Years 2010-2016 (2010). http://przetargi.bip.uml.lodz.pl/pokaz/plik.htm?idPlik=7416 (access: $22^{\text {nd }}$ June 2017).

Stubbs, J. \& Warnaby, G. (2015). Rethinking Place Branding from a perspective: Working with Stakeholders. In: M. Kavaratzis, G. Warnaby \& G. J. Ashworth (eds.). Rethinking Place Branding. Comprehensive Brand Development for Cities and Regions. London: Springer.

Yin, R. K. (2009). Case Study Research. Design and Methods. Los Angeles: SAGE. Zenker, S. (2009). Who's your target? The creative class as a target group for place branding. Journal of Place Management and Development, 2(1), 23-32.

Zenker, S. (2011). How to catch a city? The concept and measurement of place brands, Journal of Place Management and Development, 4(1), 40-52.

Zenker, S. \& Braun, E. (2010). Towards an integrated approach for place brand management. Presented at the 50th European regional science association congress, Jönköping, Sweden, http://www.ekf.vsb.cz/export/sites/ekf/projekty/ cs/weby/esf-0116/databaze-prispevku/clanky_ERSA_2010 (access: $22^{\text {nd }}$ June 2017).

\section{BUDOWANIE MARKI MIASTA NA PODSTAWIE DZIALALNOŚCI TEATRÓW MIEJSKICH}

\section{Abstrakt}

Tło badań. Wyzwanie budowania silnej marki terytorialnej jest obszarem coraz większego zainteresowania zarówno praktyków, jak i naukowców. Kultura, stanowiąca ważny element lokalnej tożsamości, coraz częściej wykorzystywana jest jako baza do budowania marki terytorialnej. Ważnym jej kreatorem są lokalne instytucje kultury, takie jak teatry, muzea, galerie. W Polsce publiczne instytucje kultury maja duży stopień autonomii wobec lokalnych władz/lokalnej administracji i ich skuteczne włączanie w procesy budowania marki terytorialnej wymaga przyjęcia adekwatnego podejścia.

Cel badań. Celem artykułu jest identyfikacja form współpracy instytucji kultury $\mathrm{z}$ administracją lokalną na rzecz budowania marki miasta. Ze względu na zróżnicowana 
rolę poszczególnych rodzajów instytucji kultury w procesie komunikowania marki miasta, rozważania zawężono do teatrów miejskich.

Metodologia. Do realizacji tak określonego celu wykorzystano metodę studium przypadku. Analizie poddano miasta Łódź i Białystok. Dobór miast wiązał się z wyraźnie zaakcentowana rolą kultury w strategiach rozwoju obydwu ośrodków. $\mathrm{W}$ ramach studiów przypadku zostały przeprowadzone indywidualne wywiady pogłębione z zarządzającymi teatrami, jak też z kierownikami jednostek organizacyjnych zajmującymi się sfera promocji w urzędach miejskich w ośrodkach objętych analizą.

Kluczowe wnioski. Opracowanie pozwoliło: ustalić typy wspólnych projektów realizowanych przez teatry i administrację lokalna na rzecz budowania marki miasta, zdiagnozować korzyści wynikające z tej współpracy dla obu stron, a także sformułować warunki skuteczności tego typu kooperacji.

Słowa kluczowe: marka miasta, instytucje kultury, teatry, współdziałanie międzyorganizacyjne 